\title{
DNA microarray Technology and Data Analysis in Cancer Research
}

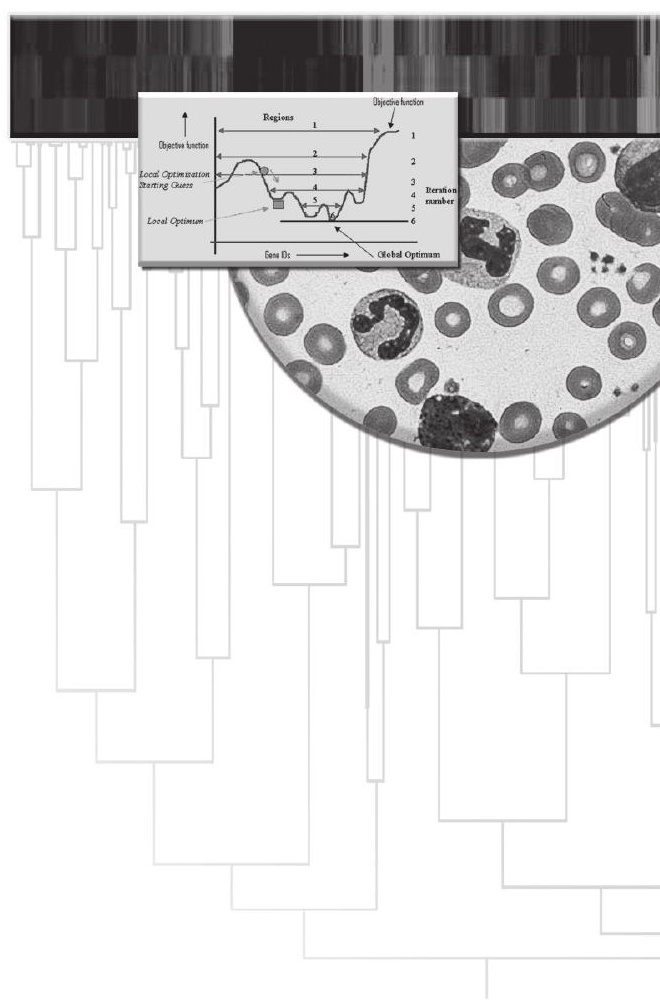


This page intentionally left blank 


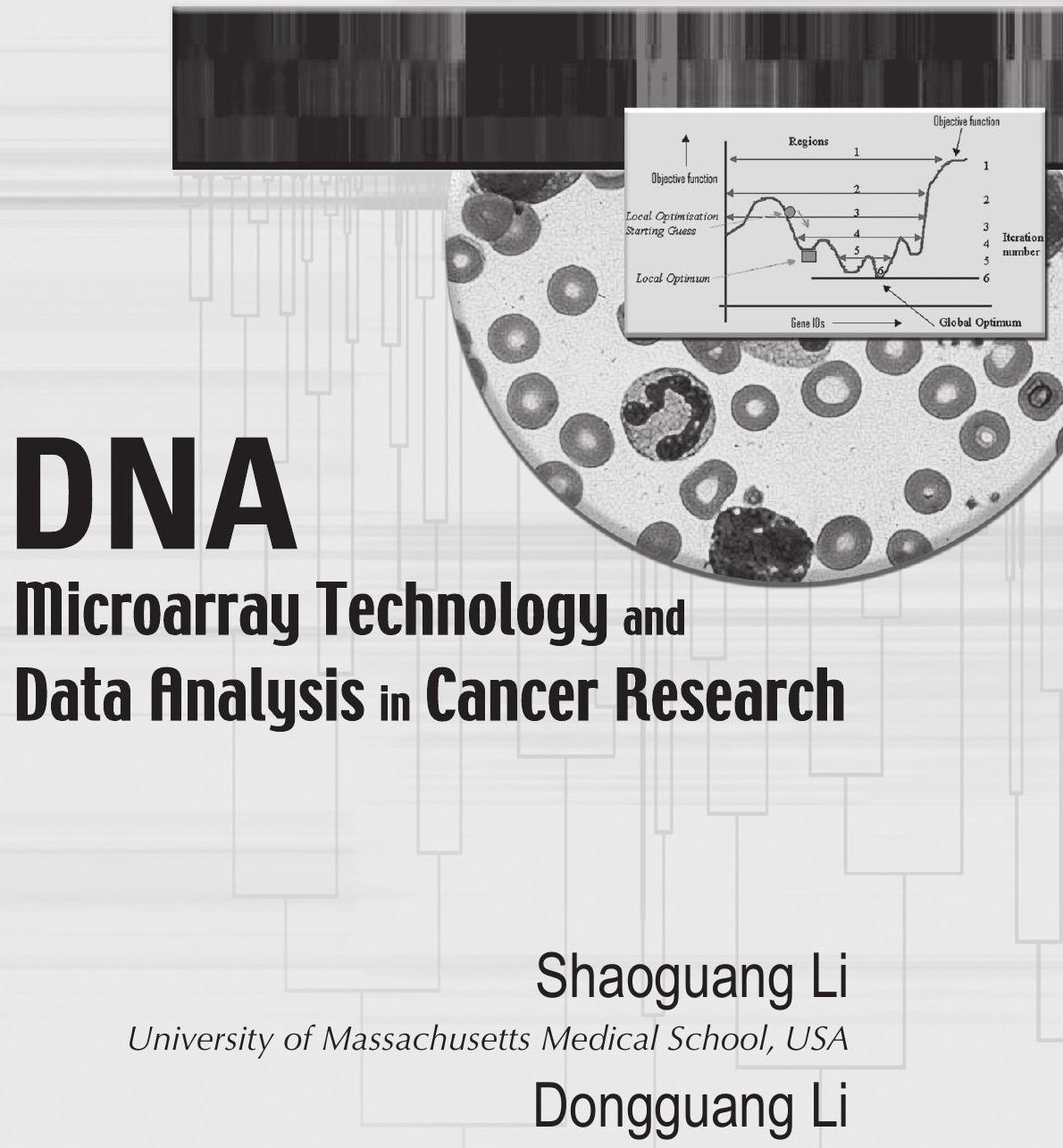

Edith Cowan University, Australia 
Published by

World Scientific Publishing Co. Pte. Ltd.

5 Toh Tuck Link, Singapore 596224

USA office: 27 Warren Street, Suite 401-402, Hackensack, NJ 07601

UK office: 57 Shelton Street, Covent Garden, London WC2H 9HE

\section{British Library Cataloguing-in-Publication Data}

A catalogue record for this book is available from the British Library.

\section{DNA MICROARRAY TECHNOLOGY AND DATA ANALYSIS IN CANCER RESEARCH}

Copyright (C) 2008 by World Scientific Publishing Co. Pte. Ltd.

All rights reserved. This book, or parts thereof, may not be reproduced in any form or by any means, electronic or mechanical, including photocopying, recording or any information storage and retrieval system now known or to be invented, without written permission from the Publisher.

For photocopying of material in this volume, please pay a copying fee through the Copyright Clearance Center, Inc., 222 Rosewood Drive, Danvers, MA 01923, USA. In this case permission to photocopy is not required from the publisher.

ISBN-13 978-981-279-045-3

ISBN-10 981-279-045-4

Typeset by Stallion Press

Email: enquiries@stallionpress.com

Printed in Singapore. 


\section{Preface}

DNA microarray technology has become a useful technique in gene expression analysis for the development of new diagnostic tools, and for the identification of disease genes and therapeutic targets for human cancers. Appropriate control for DNA microarray experiment and reliable analysis of the array data are the key to performing the assay and utilizing the data correctly. The most difficult challenge has been the lack of a powerful method to analyze the data for all genes (more than 30000) simultaneously and to use the microarray data in a decision-making process.

In this book, we attempt to describe DNA microarray technology and data analysis by pointing out current advantages and disadvantages of the technique and available analytical methods. An important part of the book is that we will include some new ideas and analytical methods based on our own experience in DNA microarray study and analysis. We believe that our new way of interpreting and analyzing the microarray data will bring us closer to success in decision making using the information obtained through DNA microarray technology. 
This page intentionally left blank 


\section{Introduction of Authors}

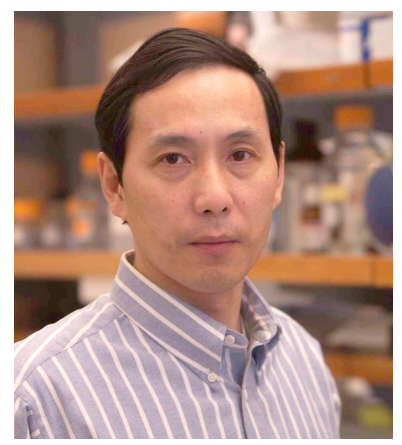

Shaoguang Li, M.D., Ph.D.

Division of Hematology/Oncology

Department of Medicine

University of Massachusetts Medical School

Lazare Research Building \#315

364 Plantation Street

Worcester, MA 01605

USA

Tel: +1 5088561691

Email: Shaoguang.Li@umassmed.edu

Dr. Shaoguang Li obtained his M.D. degree from China Medical University, Shenyang, China; and his Ph.D. degree from Tulane University, New Orleans, Louisiana, USA. He did his postdoctoral training at Harvard Medical School in Boston, Massachusetts, USA; and began his independent scientific career at The Jackson Laboratory, Bar Harbor, Maine, USA. He is currently an Associate Professor at the University of Massachusetts Medical School, Worcester, Massachusetts, USA. His research interests have been in understanding the molecular basis of leukemogenesis and in developing effective and curative therapeutic strategies. He has made significant contributions to the research field of Philadelphia chromosome-positive $\left(\mathrm{Ph}^{+}\right)$ leukemia using a mouse leukemia model, including the discovery of the roles of Src family kinases and leukemia stem cells in leukemia initiation/progression and resistance to kinase inhibitors. One of his main research focuses is on understanding the biology of leukemia stem cells for developing curative anti-stem cell therapy for $\mathrm{Ph}^{+}$leukemia and other types of cancer. 


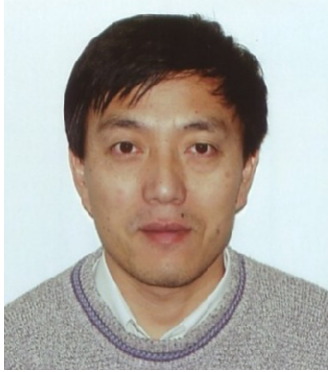

\section{Dongguang Li, Ph.D.}

School of Computer and Information Science Edith Cowan University

2 Bradford Street

Mount Lawley, WA 6050

Australia

Tel: +61 893706358

Email: d.li@ecu.edu.au

Dr. Dongguang Li is currently an Associate Professor in the School of Computer and Information Science at Edith Cowan University, Australia, and is a member of the Institute of Electrical and Electronics Engineers (IEEE) and the Optical Society of America (OSA). He obtained an M.Eng. degree in optical engineering from the University of Shanghai for Science and Technology, China, in 1984; and a Ph.D. in physics from the University of New South Wales, Australia, in 1994.

He has had a productive research career spanning more than two decades. During this time, he has made important and significant contributions to a variety of scientific fields, in particular the broad fields of optical engineering, global optimization, and information technology.

His research interests have been in global optimization algorithms and their applications in intelligent ballistics image processing and optical thin film design. He invented a unique and innovative true global optimization algorithm for optical thin film design. He is the author of the optical thin film design software, OpteFilm, and its upgraded version, OnlyFilm. He has also established a database system based on ballistics image processing for firearm identification, for which he was awarded the 2006 Australian B-HERT (Business-Higher Education Round Table) Award for best research and development collaboration. Recently, he has expanded his research interests to the field of microarray data mining. 


\section{Contents}

Preface $\quad$ V

Introduction of Authors vii

Chapter 1 DNA Microarray Technology 1

1.1. Experimental Procedure 2

1.2. Experimental Design 4

1.3. Quality Control 6

1.4. Interpretation of DNA Microarray Data 8

1.5. Advantages and Disadvantages 8

Chapter 2 Applications of DNA Microarray Technology in Cancer Research 11

2.1 Solid Tumors 11

2.2 Blood Cancers 12

2.3. Our DNA Microarray Study Using Mouse Model of BCR-ABL-Induced Leukemia 13

2.3.1. Leukemia mouse model study 15

2.3.2. Cell line study 19

Chapter 3 Current Analytical Methods of DNA Microarray Data $\quad 21$

3.1. Experimental Design 21

3.2. Method 21 
3.2.1. Robust multi-chip averaging (RMA)

3.2.2. iterPLIER 22

3.3 Quality Control Diagnostics 25

3.3.1. Saturation 25

3.3.2. Transformed intensities across arrays 28

3.3.3. Normalized intensities across arrays $\quad 29$

3.3.4. Scatterplot of normalized intensities $\quad 30$

3.3.5. Average MA plot of normalized intensities

3.4. Statistical Analysis $\quad 32$

3.4.1. Analysis of variance (ANOVA) model 32

3.4.2. Contrasts 33

3.5. Coefficient of Variation Analysis 36

\section{Chapter 4 A Novel Method for DNA Microarray Data} Analysis: SDL Global Optimization Method 37

4.1. Research Subjects 38

4.2. Experimental Design 39

4.2.1. Rationale 39

4.3. Fold Change Analysis $\quad 40$

4.4. More Information on SDL Global Optimization 51

4.4.1. Genetic algorithms (GAs) 53

4.4.2. SDL global optimization algorithms $\quad 54$

\section{Chapter 5 Applications of the SDL Global Optimization} Method in DNA Microarray Data Analysis

5.1. Leukemia Cell Line Study 55

5.1.1. Introduction $\quad 55$

5.1.2. Datasets 55

5.1.3. Analysis strategies 55

5.1.4. Discussion and conclusion 62

5.2. Analyses of Publicly Available Human

Microarray Data

5.2.1. Introduction 63

5.2.2. Datasets 70 
5.3. Overall Methodology

5.3.1. Orthogonal arrays (OAs) and sampling procedure

5.3.2. Objective function

74

5.3.3. Search space reduction for global search 76

5.3.4. Mathematical form of SDL optimization 80

5.3.5. Multi-subset class predictor

5.3.6. Validation (predicting through a voting mechanism)

5.4. Experimental Results

5.5. Discussion

5.6. Conclusion

99

Chapter 6 General Discussion and Future Directions 